\title{
Asimetrične korelacije na tržištu kapitala u Hrvatskoj
}

\section{Kunovac, Davor}

Source / Izvornik: Odabrani prijevodi, 2011, 2, 1 - 24

Journal article, Published version

Rad u časopisu, Objavljena verzija rada (izdavačev PDF)

https://doi.org/10.3326/op.7

Permanent link / Trajna poveznica: https://urn.nsk.hr/urn:nbn:hr:242:992255

Rights / Prava: Attribution-NonCommercial-NoDerivatives 4.0 International/ImenovanjeNekomercijalno-Bez prerada 4.0 međunarodna

Download date / Datum preuzimanja: 2023-04-26
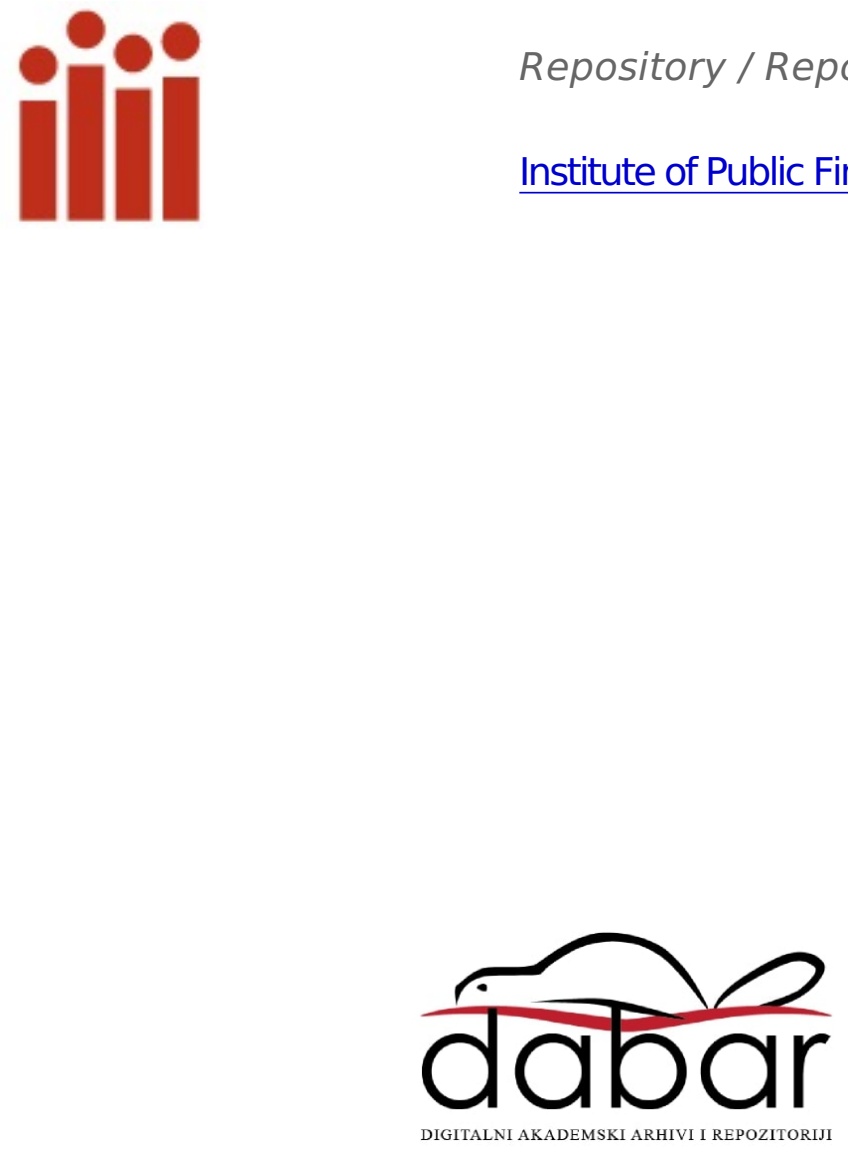
Smičiklasova 2I

Io ooo Zagreb

Tel. oI / 4886-444, 4819-363

Fax OI/4819-365

ured@ijf.hr

www.ijf.hr

\section{ODABRANI PRIJEVODI}

ISSN I $847-7445$

\section{BR. 7/II}

\section{ASIMETRIČNE KORELAGIJE NA TRŽIŠTU KAPITALA U HRVATSKOJ}

\author{
Davor KUNOVAC* \\ Hrvatska narodna banka, Zagreb \\ dkunovac@hnb.hr
}

\author{
Izvorni znanstveni članak ${ }^{* *}$ \\ JEL: GII, GI2 \\ UDK: 336.7 \\ DOI: $10.3326 /$ op.7
}

\section{Sažetak}

U ovome radu analizirane su razlike u funkcioniranju tržišta kapitala u Hrvatskoj za mirnih vremena u odnosu na turbulentna tržišna razdoblja. Markov Regime Switching metodologijom su formalno identificirani režimi na domaćem tržištu kapitala pri čemu je pokazano da su korelacije među prinosima za turbulentnog režima značajno veće u odnosu na mirni režim, u prosjeku preko dva puta. Ovakva je asimetričnost u korelacijama pokazana kako za korelacije među dionicama CROBEX-a, tako i u odnosu između nacionalnih burzovnih indeksa europskih zemalja. U kontekstu diversifikacije međunarodnih portfelja, rezultati analize sugeriraju kako je potencijalna korisnost diversifikacije koju investitori mogu ostvariti držanjem međunarodnih portfelja za turbulentnih razdoblja relativno ograničena. Pored toga, out-of-sample analizom ulaganja u odabrane dionice CROBEX-a, modelski se ilustriraju gubici koje investitori realiziraju pri redovitoj optimizaciji portfelja u slučaju da ignoriraju asimetričnosti na tržištu kapitala. Provedena analiza sugerira da često kritizirani Mean Variance model optimizacije portfelja pokazuje dobre performanse u primjeni ako se vodi računa o asimetričnosti korelacija na tržištu kapitala.

Ključne riječi: optimizacija portfelja, Markov Regime Switching, CAPM

\footnotetext{
* Autor zahvaljuje Sheri Markose i anonimnim recenzentima na korisnim komentarima.

** Primljeno: I. lipnja 2010.

Prihvaćeno: 2. studenog 2010. 


\section{Uvod i motivacija}

Posebna pažnja $\mathrm{u}$ istraživanjima $\mathrm{u}$ području financijske ekonomije posvećena je fenomenu asimetričnih korelacija među cijenama dionica (Ramchand i Susmel, 1997; Longin i Solnik, 200I; Ang i Chen, 2002; Ang i Bekaert, 2004; Markose i Yang, 2008). Asimetričnost se u ovom kontekstu odnosi na činjenicu da se korelacija među prinosima značajno razlikuje tijekom turbulentnih u odnosu na mirna tržišna razdoblja. Tako je za vrijeme mirnih perioda na tržištima kapitala, korelacija među prinosima općenito niska što investitorima omogućava uspješnu diversifikaciju portfelja, sukladno njihovom odnosu prema riziku. S druge strane, turbulentna tržišta su karakterizirana naglim porastom korelacija među dionicama i diversifikacija portfelja je u takvim uvjetima značajno otežana. Budući da recentna literatura uglavnom istražuje asimetričnosti na razvijenim tržištima kapitala te u kontekstu novih članica EU i vodeća tržišta srednje i istočne Europe (npr. Syriopoulos, 2004; Égert i Kočenda, 2007; Syllignakis i Kouretas, 2006), malo je dostupnih informacija o eventualnoj heterogenosti u dinamici domaćeg tržišta. Stoga ova analiza nastoji formalno identificirati režime na tržištu kapitala u Hrvatskoj, sagledati uzroke njihova postojanja te provjeriti da li se pravovremena identifikacija tržišnih režima može iskoristiti pri optimizaciji portfelja u primjeni. Pored korelacija među prinosima na domaćem tržištu, analizira se i asimetričnost međuodnosa domaće burze s burzama nove i stare Europe. Ovime se u prvome redu želi postići bolji uvid u razinu integracije domaćeg tržišta s tržištima Europske unije te, pored toga, i analizirati potencijal diversifikacije međunarodnih portfelja širenjem na dionice tržišta nove Europe.

Prirodno se postavlja pitanje uzroka promjene režima na tržištima kapitala. Recentna literatura suglasna je u mišljenju kako je glavni okidač naglih promjena na razvijenim tržištima kapitala (očekivana) promjena agregatne realne aktivnosti. Uz pretpostavku da cijena dionice reflektira sadašnju vrijednost očekivanih isplata svih budućih novčanih tokova vezanih uz dionicu (tj. dividendi), jasno je da tržišta reagiraju na promjene u realnom poslovnom ciklusu. Na primjer, u slučaju kada tržište očekuje pad realne aktivnosti u skoroj budućnosti, očekuje i slabije poslovne rezultate kompanija na burzi te u konačnici i niže profite u vidu smanjenih dividendi. Krajnja posljedica ovog očekivanog pada realne aktivnosti je tako i pad cijene dionice. Iz tog razloga su indeksi burzi često dobri prethodeći indikatori ukupne realne gospodarske aktivnosti ${ }^{\mathrm{I}}$. Ova je veza ilustrirana na slici I. koja uspoređuje svjetski output i svjetski indeks cijena dionica u posljednjih dvadeset godina. U prošlosti je dinamika na tržištima kapitala prethodila realnim kretanjima i do nekoliko kvartala unaprijed, dok je posljednjih nekoliko godina sinhroniziranost realnog i financijskog sektora dodatno povećana. Na globalnoj razini, ova veza između realne aktivnosti i tržišta kapitala je postojana dok se na razini pojedine zemlje ona ipak teže utvrđuje. Posebice je to slučaj za mala otvorena gospodarstva, poput hrvatskog, gdje relacije sa vanjskim faktorima u velikoj mjeri utječu na dinamiku domaćih ekonomskih indikatora, kako onih iz realnog sektora tako i na sama financijska tržišta.

${ }^{\mathrm{I}} \mathrm{U}$ kontekstu sposobnosti tržišta kapitala da predvide realna kretanja često je citirana opaska Paula Samuelsona kako su tržišta kapitala predvidjela devet od posljednjih pet recesija. (Samuelson, I966). 
Slika I.

Agregatni indeks svjetskih burzi te svjetski BDP

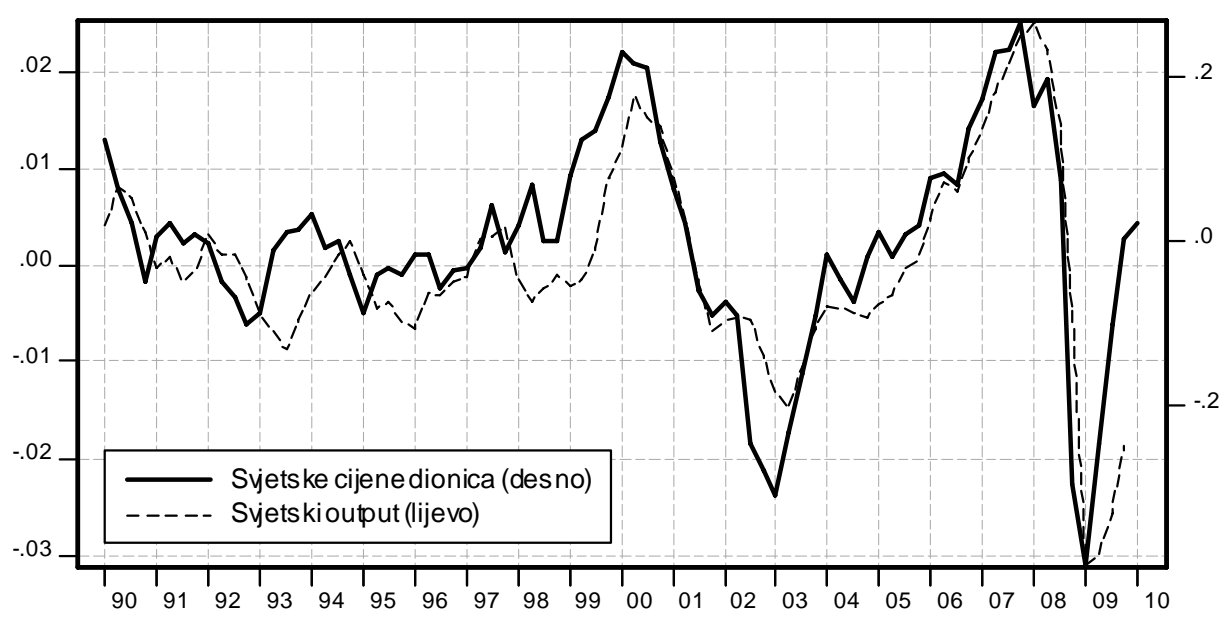

Napomena: Obje serije su prikazane kao postotna odstupanja od dugoročnog trenda pri čemu je rastava serija na trend i ciklus dobiven korištenjem Hodrick Prescott filtra.

Dinamika korelacije među nacionalnim burzama ima izravne posljedice na performanse međunarodnih portfelja. Jedan od osnovnih razloga zbog kojih investitori drže internacionalne portfelje je mogućnost kvalitetnije diversifikacije portfelja u svrhu zadovoljavajuće distribucije rizika. Preduvjet uspješne internacionalne diversifikacije je da većina šokova koji pogađaju nacionalna financijska tržišta budu idiosinkratski, tj. specifični za pojedinu državu pri čemu ne dolazi do značajnog prelijevanja na preostala tržišta. No, imajući na umu da tijekom turbulentnih perioda na tržištima kapitala veze među prinosima naglo jačaju, potpunu korisnost od diversifikacije tada je teško materijalizirati. Kako bi se ova dinamika u korelacijama među prinosima mogla iskoristiti pri optimizaciji portfelja u primjeni, potrebno je identificirati osnovne kanale internacionalne propagacije financijskih šokova. Primjerice, posljedica povećane ekonomske integracije na međunarodnoj razini je da globalni makroekonomski šokovi simultano djeluju na financijska tržišta putem nacionalnih kanala između realnog sektora i financijskih tržišta. Zatim, realni šok jedne zemlje može djelovati na fundamente druge zemlje i posljedično i na njezin financijski sektor. Pored toga, korelacije među prinosima mogu značajno porasti i zbog razloga koji nisu vezani uz realna kretanja pojedinih zemalja, njihove fundamente, promjene u politikama i sl. Prinosi na burzama zemalja koje nisu pod značajnim utjecajem zajedničkih šokova tako često pokazuju iznenađujuće snažnu povezanost koju je teško objasniti sličnošću u fundamentima ili direktnom povezanošću financijskih tržišta. Propagacija ovakvog šoka naziva se zaraza. Ova se pojava povezuje s činjenicom da investitori za loših tržišnih razdoblja često oponašaju jedan drugoga bez obzira na makroekonomsko okruženje². Konačno, investitori ponekad radije prate kretanja agregatnog tržišta, u uvjerenju da ono već sadrži svu relevantnu informaciju, i stoga se ne odlučuju za vlastitu, često skupu i zahtjevnu analizu tržišta. Internacionalna propagacija šokova detaljno se analizira npr. u Calvo i Reinhart (1996), Calvo i

${ }^{2}$ Mullainathan (1998) daje objašnjenje povećane korelacije na tržištima kapitala za turbulentnih razdoblja sa stajališta psihologije. U radu je modelski argumentirano kako se investitori za turbulentnih perioda na nesavršen način prisjećaju prošlih 
Mendoza (2000), i Forbes i Rigobon (2002).

Na mikro razini, odnosno pri optimizaciji pojedinog dioničkog portfelja, pravovremena identifikacija režima u kojemu se tržište trenutno nalazi ima presudan utjecaj na performanse portfelja. Razlog tomu je činjenica da važan input pri odabiru optimalnih portfelja čine očekivanja i varijance prinosa pojedinih dionica, te korelacije među njima. Budući da se ovi momenti značajno razlikuju u različitim režimima tržišta, postoji mogućnost odabira neoptimalnih portfelja u slučaju da investitor anticipira pogrešan režim u bliskoj budućnosti ili čak ignorira njihovo postojanje. Primjerice, klasična Markowitzeva Mean Variance (MV) teorija optimizacije portfelja garantira optimalnu alokaciju jedino uz pretpostavku da su stvarne vrijednosti očekivanja, varijance i korelacija za rizičnu imovinu od interesa zaista poznate (Markowitz, 1952). Naravno, ovaj preduvjet u stvarnome svijetu nikada nije ispunjen te je navedene veličine potrebno procjenjivati iz dostupnog uzorka. Tako je MV metodologija optimizacije često kritizirana upravo zbog neobične alokacije imovine u portfelju pri čemu je zastupljenost određenih dionica iznenađujuće velika (odnosno mala) s obzirom na njihovu recentnu dinamiku (Black i Litterman, I992). Algoritam tako redovito preferira dionice karakterizirane visokim procjenama očekivanih vrijednosti te niskom volatilnošću. No, procjene očekivanja, volatilnosti i korelacija u primjeni nisu stabilne kroz vrijeme i stoga parametri procijenjeni na dostupnom uzorku podataka obično nisu u skladu s trenutnom dinamikom dionica od kojih konstruiramo portfelj. Iz tog razloga, MV model optimizacije na temelju netočnih inputa često alocira imovinu na neoptimalan način što kao krajnju posljedicu ima portfelje s nezadovoljavajućim performansama. Unatoč činjenici da je asimetričnost na razvijenim tržištima kapitala već dulje vrijeme relativno poznata pojava na tržištima, prvi formalni modeli koji uzimaju u obzir ovu činjenicu razvijeni su tek u posljednjih desetak godina.

Ang i Bekaert (2004) tako nalaze da globalno tržište kapitala redovito funkcionira pod jednim od dva moguća režima i utvrđuju postojanje negativne vezu između očekivanih prinosa te volatilnosti za svaki režim. Prvi, mirni režim, karakteriziran je pozitivnim prinosima te niskom volatilnošću i ovdje su prinosi na imovinu relativno slabo korelirani što u konačnici omogućava uspješnu diversifikaciju portfelja. Suprotno tomu, svjetsko tržište kapitala povremeno ulazi u turbulentni režim u kojemu su prinosi niski ili čak negativni, volatilnost je velika, dok je korelacija značajno veća u odnosu na mirni režim. Konačno, autori ilustriraju korisnost koju investitori mogu ostvariti na međunarodnom tržištu kapitala uvažavajući postojanje režima. Markose i Yang (2008) provode sličnu analizu, no sada za tržište kapitala Ujedinjenog Kraljevstva. Autori uspješno identificiraju postojanje turbulentnog/mirnog režima u prinosima na FTSE IOo. Kao i u slučaju međunarodnih investitora i ovdje je pokazano da uvažavanje režima bitno poboljšava performanse portfelja.

U obje spomenute analize pretpostavlja se da tržište kapitala naglo i uglavnom bez ikakve naznake prelazi iz jednog režima u drugi što je svojstvo koje zaista i opažamo u primjeni. Sukladno tomu, momenti dionica - očekivani prinosi, volatilnosti i korelacije među njima također ovise o trenutnom režimu u kojemu se tržište nalazi. Imajući na umu da u stvarnosti ne opažamo varijable koje bi pružale

kriznih razdoblja te kao posljedica, korelacija sjećanja, a ne fundamenata uzrokuje povećanje korelacije u cijenama. 
izravnu informaciju o trenutnom režimu tržišta potrebno je bilo osmisliti formalni okvir za određivanje režima. U tu svrhu Ang i Bekaert (2004) te Markose i Yang (2008) koriste Markov Regime Switching (MRS) metodologiju (Hamilton, 1998; 1999; 2004) pri čemu se stanje tržišta modelira kao slučajna varijabla koju ne opažamo i stoga je moguće procijeniti vjerojatnosti da se tržište u danom periodu nalazi u određenom režimu.

Nastavljajući se na spomenutu literaturu ovaj rad bavi se postojanjem asimetričnih korelacija u kontekstu domaćeg tržišta kapitala. U prvome koraku se proučava veza domaćeg tržišta s tržištima nekoliko europskih zemalja. Rezultati MRS modela sugeriraju kako sva promatrana tržišta funkcioniraju pod dva bitno različita režima. U mirnom režimu, prinosi su visoki uz nisku volatilnost, dok su za turbulentnog režima tržišta karakterizirana visokom volatilnošću te negativnim prinosima. Nadalje, sve izraženija vremenska sinhroniziranost tržišnih režima u analiziranim zemljama sugerira visok stupanj integriranosti tržišta nove i stare Europe i Hrvatska ovdje nije iznimka. Konačno, nakon identifikacije režima, ispituje se i postojanje asimetričnih korelacija među dioničkim indeksima. Analiza mjesečnih prinosa pokazuje kako je korelacija domaćeg sa stranim tržištima u prosjeku preko dva puta viša za turbulentnih perioda u odnosu na korelacije u mirnim razdobljima. Ovakva je asimetričnost utvrđena kako u odnosu prema razvijenim zemljama tako i prema ostalim zemljama srednje i istočne Europe.

Nakon analize odnosa domaćeg tržišta sa tržištima Europe, detaljno se proučava i korelacija prinosa unutar domaćeg tržišta kapitala. U prvome koraku su MRS metodologijom uspješno identificirana dva tržišna režima u prinosima na CROBEX, mirni i turbulentni režim. Kao i u slučaju razvijenih tržišta formalno je pokazano da su za turbulentnog režima korelacije među odabranim dionicama značajno veće nego za mirnih razdoblja. Nakon toga provedena je i out-of-sample analiza pri čemu je pokazano da uvažavanje asimetričnosti korelacija u značajnoj mjeri poboljšava performanse standardnog MV modela optimizacije portfelja na domaćem tržištu kapitala ${ }^{3}$. Out-of-sample analiza provedena je na periodu 2007-20Io. godine kako bi se model testirao i tijekom perioda snažnog rasta, kao i za perioda pada CROBEX-a. Za razdoblja rasta, MRS portfelji temeljeni na mirnodopskim inputima perzistentno ostvaruju veće prinose od standardnog MV modela, a uz istu razinu sklonosti prema riziku. S druge strane, za turbulentnog razdoblja pada burze tijekom nedavne financijske krize, MRS model je relativno brzo anticipirao nastupanje turbulentnog režima i shodno tome gotovo sva sredstva alocirao u bezrizičnu imovinu. Standardni MV model je zbog ignoriranja režima reagirao tromije te je i tijekom pada burze držao relativno velik udio rizične imovine u portfelju te u konačnici i ostvario puno lošije rezultate za turbulentnog razdoblja.

Ovaj rad na nekoliko načina nadograđuje postojeću literaturu. U prvom redu cilj rada je za različite režime na konzistentan i vjerodostojan način izmjeriti karakteristike hrvatskog tržišta kapitala te jačinu veze domaćeg i stranih tržišta za razne faze u realnom poslovnom ciklusu. Nadalje, dobiveni

\footnotetext{
${ }^{3}$ Mean Variance modeli za hrvatsko tržište kapitala su testirani u nekoliko analiza. Primjerice, Fruk i Huljak (20o4) i Jakšić (2007) testiraju performanse MV portfelja za sastavnice CROBEX-a, problem nesinhronog trgovanja na domaćem tržištu analizira se u Latković (2OOI), rizik nelikvidnosti u Latković i Boršić (2000), i problem korisnosti internacionalne diversifikacije portfelja u Latković (2000). Iako dostupni radovi analiziraju bitna pitanja za domaće tržište kapitala, implementirani modeli
} 
rezultati sugeriraju da portfelji dobiveni Markowitzevom Mean Variance metodologijom pokazuju dobra svojstva u slučaju da se vodi računa o asimetričnosti parametara modela. S druge strane, performanse standardnog MV modeli u kojima se asimetričnost ignorira značajno zaostaju. Srodna literatura do sada je analizirala modele alokacije imovine temeljene na asimetričnim inputima isključivo za razvijena tržišta kapitala. U kontekstu korištene metodologije, međuodnos između prinosa pojedinih dionica te agregatnog indeksa modelirana je korištenjem standardnog CAPM-a, kao i u Ang i Bekaert (2004) te Markose i Yang (2008). No za razliku od spomenutih radova, ovdje se uvažava vremenska nestabilnost CAPM relacija. Rezultati analize sugeriraju da ignoriranje nestabilnosti CAPM-a kroz vrijeme donosi značajne gubitke. Konačno, poznato je da je procjena parametara $\mathrm{u}$ Markov Regime Switching modelima zahtijevan problem u numeričkom smislu (Hamilton, 1994). Razlog tomu je činjenica da je zahtjevno maksimizirati funkciju vjerodostojnosti modela i stoga je teško prosuditi u kojoj mjeri procijenjeni parametri zaista odgovaraju stvarnim podacima. Iz tog razloga, vjerodostojnost procijenjenog modela testirana je jednostavnim Monte Carlo eksperimentom.

Struktura ostatka rada je sljedeća. U drugom odlomku iznesene su osnove Regime Switching metodologije. Treći odlomak bavi se asimetričnostima u korelacijama između hrvatskog tržišta te tržišta zemalja EU. Četvrti odlomak izlaže model optimizacije portfelja koji uzima u obzir asimetričnosti na tržištu te predstavlja rezultate optimizacije portfelja sastavljenog od odabrane tri dionice hrvatskog tržišta kapitala. Peti odlomak daje zaključak.

\section{Metodologija}

Glavni rezultati ovoga rada temelje se na pretpostavci da je moguće formalno identificirati režime na tržištima kapitala. Identifikacija je moguća uvjetovanjem na determinante promjene režima, primjerice na varijable realne aktivnosti ili različite financijske indikatore. Osim toga, režime na tržištu možemo razdvojiti i direktnim uvjetovanjem na distribuciju za koju pretpostavljamo da generira vremensku seriju prinosa, što je pristup na kojemu se temelji glavni tehnički alat ovog rada Markov Regime Switching metodologija.

\section{I. Markov Regime Switching regresije}

Nagle promjene $u$ dinamici vremenske serije prinosa $y_{t}$ uspješno se modeliraju korištenjem MRS modela. Uz pretpostavku da postoje dva bitno različita režima (bull/bear ili mirni/turbulentni), varijabla od interesa pripada jednoj od dvije normalne distribucije, već u ovisnosti o trenutnom stanju svijeta/tržišta $S_{t}$ :

$$
y_{t} \mid\left(S_{t}=i\right): N\left(\mu_{i}, \sigma_{i}^{2}\right), \text { za } i=1,2, t=1, \ldots, T,
$$


ili ekvivalentno, u formi regresije:

$$
y_{t}= \begin{cases}\mu_{1}+\sigma_{1} \varepsilon_{t} & \text { ako } S_{t}=1 \\ \mu_{2}+\sigma_{2} \varepsilon_{t} & \text { ako } S_{t}=2\end{cases}
$$

pri čemu je $S_{t}$ trenutno stanje tržišta, $\mu_{1}$ i $\mu_{2}$ su očekivanja, $\sigma_{1}$ i $\sigma_{2}$ standardne devijacije za dva režima i $\left\{\varepsilon_{t}\right\}_{t=-\infty}^{\infty}$ je standardni bijeli šum. Budući da realizacije procesa $\left\{S_{t}\right\}_{t=-\infty}^{\infty}$ u primjeni $n e$ opažamo standardno se pretpostavlja da on prati diskretan Markovljev proces prvog reda na prostoru stanja $S=\{$ mirno, turbulentno $\}=\{1,2\}$. U tom slučaju su vjerojatnosti tranzicije procesa karakterizirane s dva osnovna svojstva:

$$
\begin{aligned}
& P\left(S_{t}=j \mid S_{t-1}=i\right)=p_{i j}, \forall t(\text { vremenskahomogenostvjerojatnostiprelaska) } M 1 \\
& P\left(S_{t}=j \mid S_{t-1}=i, S_{t-2}=k, \ldots\right)=P\left(S_{t}=j \mid S_{t-1}=i\right)(\text { Markovljevosvojstvo), } M 2
\end{aligned}
$$

i tranzicijske vjerojatnosti sada formiraju matricu čije elemente treba procijeniti:

$$
\left[\begin{array}{ll}
p_{11} & p_{12} \\
p_{21} & p_{22}
\end{array}\right]=\left[\begin{array}{ll}
P\left(S_{t}=1 \mid S_{t-1}=1\right) & P\left(S_{t}=2 \mid S_{t-1}=1\right) \\
P\left(S_{t}=1 \mid S_{t-1}=2\right) & P\left(S_{t}=2 \mid S_{t-1}=2\right)
\end{array}\right]=\left[\begin{array}{cc}
P & 1-P \\
1-Q & Q
\end{array}\right]
$$

U kontekstu modeliranja naglih promjena na tržištu kapitala, svojstvo Mi osigurava da su vjerojatnosti tranzicije među režimima konstantne kroz vrijeme, dok M2 povlači da je za stanje tržišta u sljedećem periodu relevantno jedino trenutno stanje tržišta.

\section{I.I. Procjena parametara}

Skup parametara koji se procjenjuju $\boldsymbol{\theta}=\left(\mu_{1}, \mu_{2}, \sigma_{1}, \sigma_{2}, p_{11}, p_{22}\right)$ sastoji se od očekivanja i standardnih devijacija za dva režima $\left(\mu_{1}, \mu_{2}, \sigma_{1}, \sigma_{2}\right)$, te vjerojatnosti ostanka tržišta u svakom od stanja $\left(p_{11}\right.$ i $\left.p_{22}\right)$. Budući da proces stanja tržišta ne opažamo funkcija vjerodostojnosti $L\left(\boldsymbol{\theta} ; y_{1}, \ldots, y_{T}\right)$ izvodi se u sljedećem nizu koraka.

Uočimo najprije da vrijedi:

$$
\begin{gathered}
\ln L\left(\boldsymbol{\theta} ; y_{1}, \ldots, y_{T}\right)=\sum_{t=1}^{T} \ln f\left(y_{t} \mid I_{t-1}\right)=\sum_{t=1}^{T} \ln \left(\sum_{s_{t}=1}^{2} f\left(y_{t}, s_{t} \mid I_{t-1}\right)\right) \\
=\sum_{t=1}^{T} \ln \left(\sum_{s_{t}=1}^{2} f\left(y_{t} \mid s_{t}, I_{t-1}\right) f\left(s_{t} \mid I_{t-1}\right)\right)
\end{gathered}
$$

gdje je $I_{t-1}=\left\{y_{1}, \ldots, y_{t-1}\right\}$ informacija dostupna investitoru u trenutku $t-1$, dok su uvjetne gustoće $f\left(y_{t} \mid s_{t}, I_{t-1}\right)=f\left(y_{t} \mid s_{t}\right)$ poznate iz (I). Nadalje, gustoće $f\left(s_{t} \mid I_{t-1}\right)=P\left(S_{t}=s_{t} \mid y_{1}, \ldots, y_{t-1}\right)$ 
računaju se iterativno korištenjem Hamiltonovog filtra (Hamilton, I989; 1994) u dva koraka:

$$
\begin{aligned}
& P\left(S_{t}=i \mid I_{t-1}\right)=P\left(S_{t}=i, \cup_{j \in\{1,2\}}\left(S_{t-1}=j\right) \mid I_{t-1}\right) H 1 \\
&= \sum_{j=1}^{2} P\left(S_{t}=i, S_{t-1}=j \mid I_{t-1}\right) \\
&= \sum_{j=1}^{2} P\left(S_{t}=i \mid S_{t-1}=j, I_{t-1}\right) P\left(S_{t-1}=j \mid I_{t-1}\right) \\
&= \sum_{j=1}^{2} p_{j i} P\left(S_{t-1}=j \mid I_{t-1}\right) . \\
& P\left(S_{t}=i \mid I_{t}\right)=\frac{f_{S_{t}, y_{t} \mid I_{t-1}}\left(i, y_{t} \mid I_{t-1}\right)}{f\left(y_{t} \mid I_{t-1}\right)} H 2 \\
&=\frac{f_{y_{t} \mid S_{t,} I_{t-1}}^{2}\left(y_{t} \mid i, I_{t-1}\right) P\left(S_{t-1}=i \mid I_{t-1}\right)}{\sum_{j=1}^{2} f_{y_{t} \mid S_{t,} I_{t-1}}\left(y_{t} \mid j, I_{t-1}\right) P\left(S_{t-1}=j \mid I_{t-1}\right)} .
\end{aligned}
$$

Kako bismo izračunali vektor procjena $\hat{\boldsymbol{\theta}}$ koji je u najvećoj mogućoj mjeri konzistentan s opaženim podacima, maksimiziramo funkciju $\ln L\left(\boldsymbol{\theta} ; y_{1}, \ldots, y_{T}\right)$ koristeći numeričku optimizaciju ${ }^{4}$.

Korištenjem gornjih relacija možemo izračunati vjerojatnosti da je tržište $u$ mirnom, odnosno turbulentnom režimu. Filtrirane vjerojatnosti $P\left(S_{t}=i \mid I_{t}\right)$ temelje se na informaciji dostupnoj do trenutka $t$ te daju vjerojatnost da je tržište u trenutku $t \mathrm{u}$ stanju $i$. Ove se vjerojatnosti računaju rekurzivno iz (H2) za dane inicijalne vrijednosti rekurzije (Hamilton, 1994). Pored toga, često su od interesa i ex-post vjerojatnosti ili izglađene vjerojatnosti $P\left(S_{t}=i \mid y_{1}, \ldots, y_{T}\right)$. Za razliku od filtriranih vjerojatnosti za njihovo se računanje koristi informacija čitavog uzorka i algoritam za njihovu konstrukciju se može naći u Kim (1994) i Hamilton (1994).

\section{Asimetričnosti na europskim tržištima kapitala}

O ovome odlomku se ispituje postojanje asimetričnosti na hrvatskom tržištu kapitala te na nacionalnim burzama nekoliko proizvoljno odabranih zemalja Europske unije. Nove članice EU reprezentirane su Češkom, Rumunjskom i Bugarskom, dok je stara Europa reprezentirana Njemačkom. Dodatno, u svrhu usporedbe analiziraju se i agregatni indeksi zemalja središnje i istočne Europe (CEEC), EU te ukupni svjetski indeks. Najprije su za svaku zemlju MRS metodologijom identificirana dva različita režima pod kojim funkcioniraju nacionalna tržišta kapitala. Nakon identifikacije nacionalnih tržišnih režima, za svaki su režim izračunate korelacije prinosa među

${ }^{4}$ Alternativno, parametri se procjenjuju korištenjem EM algoritma (Hamilton, 1990). 
pojedinim burzama. Pri izračunu su korišteni podaci na mjesečnoj frekvenciji za period 200I-2009. godine. Izvor svih podataka je Bloomberg ${ }^{5}$.

\section{I. Režimi na europskim burzama}

Tablica I. prikazuje statistike očekivanih nominalnih mjesečnih prinosa i pripadajućih standardnih devijacija za osam dioničkih indeksa izračunatih korištenjem Markov Switching regresija.

\section{Tablica I.}

Procjene osnovnih statistika za dva režima

\begin{tabular}{|c|c|c|c|c|c|c|c|c|}
\hline & Hrvatska & Češka & Rumunjska & Bugarska & SIE & Njemačka & EU & Svijet \\
\hline \multicolumn{9}{|c|}{ Očekivani prinos (\%) } \\
\hline Gijeli uzorak & 0.8 & 0.8 & I.5 & I. 8 & 0.9 & 0.6 & 0.4 & 0.3 \\
\hline Mirni režim $\left(\mu_{1}\right)$ & 2.0 & 2.3 & 3.9 & 4.2 & I. 3 & I. 8 & I.6 & I.I \\
\hline $\begin{array}{l}\text { Turbulentni režim } \\
\left(\mu_{2}\right)\end{array}$ & -I.O & $-\mathrm{I} .3$ & -8.8 & -2.8 & -2.7 & -2.3 & -0.4 & -0.8 \\
\hline \multicolumn{9}{|c|}{ Standardna devijacija (\%) } \\
\hline Cijeli uzorak & 7.5 & 6.6 & 9.5 & 9.5 & 7.2 & 5.8 & 5.2 & 4.3 \\
\hline Mirni režim $\left(\sigma_{1}\right)$ & 4.6 & 4.0 & 7.5 & 5.8 & 6.I & 3.5 & 2.6 & 2.3 \\
\hline $\begin{array}{l}\text { Turbulentni režim } \\
\left(\sigma_{2}\right)\end{array}$ & IO.4 & 7.5 & IO.I & I3.0 & I3.6 & 6.9 & 6.I & 5.5 \\
\hline$P$ & 0.98 & 0.96 & 0.99 & 0.98 & 0.99 & 0.96 & 0.96 & 0.97 \\
\hline$Q$ & 0.97 & 0.97 & 0.9I & 0.97 & 0.89 & 0.90 & 0.97 & 0.95 \\
\hline
\end{tabular}

Rezultati u tablici I. ilustriraju kako sva promatrana tržišta funkcioniraju pod jednim od dva režima s negativno koreliranim očekivanim prinosima i standardnim devijacijama. Prvi je režim karakteriziran pozitivnim prinosima uz nisku volatilnost i stoga je identificiran kao mirni režim. $\mathrm{S}$ druge strane, $\mathrm{u}$ drugom, turbulentnom režimu je volatilnost prinosa značajno viša u odnosu na mirni režim i očekivani prinosi su sada redovito negativnog predznaka. Vjerojatnosti da će tržište i u sljedećem mjesecu ostati u istom režimu (parametri $P$ i $Q$ ) su za sva tržišta blizu jedinice što ilustrira visoku perzistentnost stanja tržišta.

Prinosi na hrvatskom tržištu kapitala dobro su opisani mirnim režimom s mjesečnim prinosom od 2\% i standardnim odstupanjem od 4.6\%, te turbulentnim periodom koji nosi prinos od -I\% uz visoku volatilnost od Io.4\%. U prosjeku, tržišta zemalja CEE su u značajnoj mjeri volatilnija od promatranih razvijenih tržišta i nose veće prinose u mirnim periodima te veće gubitke za turbulentnih razdoblja. Rezultati nadalje sugeriraju kako su statistike CROBEX-a, uz Češku, relativno bliske onima u razvijenoj Europi i svijetu. S druge strane, indeksi Rumunjske i Bugarske su karakterizirani dramatičnim razlikama u prinosima među režimima.

${ }^{5}$ Tržište kapitala u Hrvatskoj je reprezentiranom indeksom CROBEX, u Češkoj indeksom PX, u Rumunjskoj indeksom BET, u Bugarskoj indeksom SOFIX, u Njemačkoj indeksom DAX. Agregatno tržište zemalja srednje i istočne Europe je reprezentirano indeksom CECE, Europske unije pripadajućim MSCI indeksom, te svjetsko tržište kapitala indeksom MXWD. U analizi su korištene zaključne dnevne cijene koje su zatim agregirane na mjesečnu razinu. 
Slika 2.

Vjerojatnosti bivanja tržišta u turbulentnom režimu za period 1999-2009.

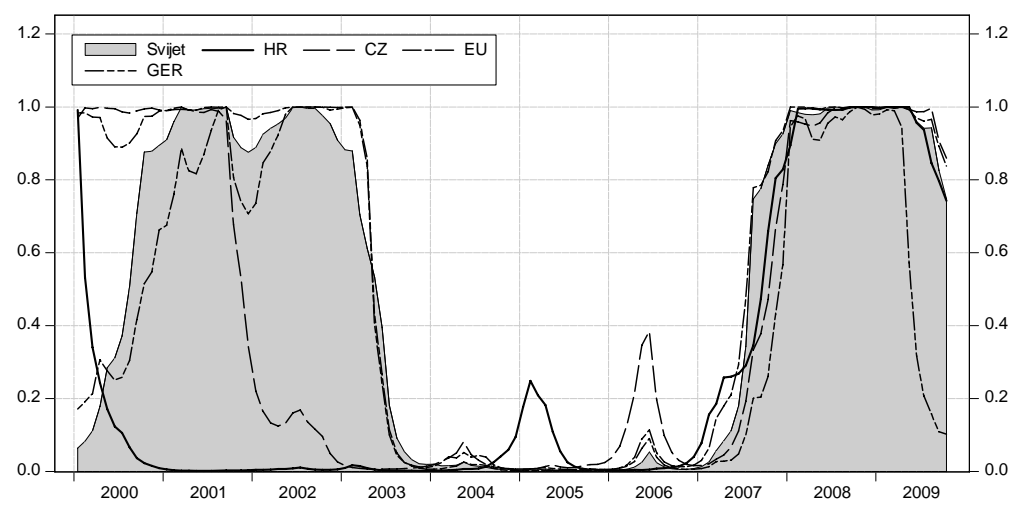

Usporedba vjerojatnosti tržišnih režima za promatrane indekse ilustrira dinamiku integracije međunarodnih tržišta kapitala. Slika 2. prikazuje ex-post vjerojatnosti bivanja promatranih tržišta u turbulentnom režimu $\mathrm{u}$ posljednjih desetak godina. Prve godine promatranog razdoblja karakterizirane su još uvijek nerazvijenim financijskim tržištima zemalja CEE, njihovom slabom integracijom $\mathrm{u}$ međunarodna tržišta kapitala te $\mathrm{u}$ konačnici i slabijim ekonomskim vezama $\mathrm{s}$ međunarodnim okruženjem. U takvim uvjetima, razlozi povećanja volatilnosti u tranzicijskim zemljama u prvom su redu posljedica domaće financijske i ekonomske aktivnosti, a manje rezultat nepovoljnih vanjskih kretanja. S druge strane, posljednjih je godina povezanost s razvijenim tržištima rasla u značajnoj mjeri, te je kao posljedica povećane integracije rasla i podudarnost mirnih odnosno turbulentnih tržišnih razdoblja. Ovo je dodatno ilustrirano na slici 3. koja prikazuje ex-post vjerojatnosti da je hrvatsko tržište kapitala u turbulentnom režimu.

\section{Slika 3.}

Nominalni mjesečni prinosi CROBEX-a te ex-post vjerojatnosti bivanja tržišta u turbulentnom režimu

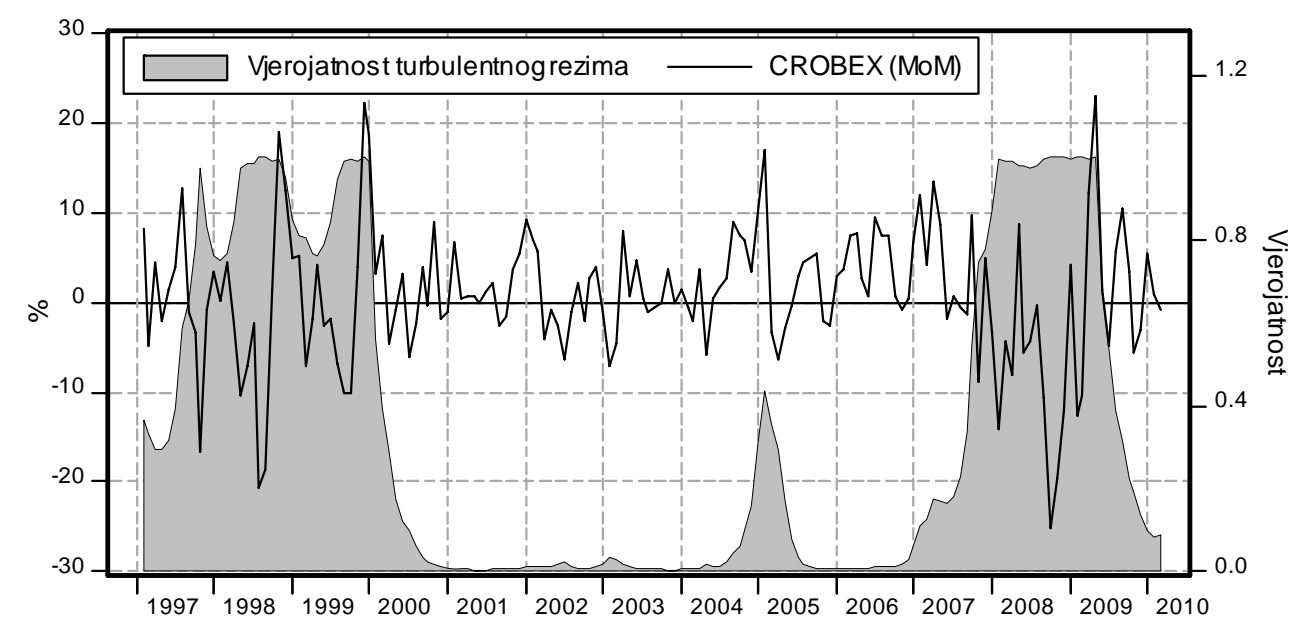

Na promatranome razdoblju korištena metodologija je identificirala dva krizna razdoblja, no s bitno različitim uzrocima. Prvo krizno razdoblje u trajanju 1997-1999. vremenski se podudara s recesijom 
domaćeg gospodarstva uzrokovanom isključivo domaćim okolnostima - tadašnjom krizom domaćeg bankarskog sektora. Za razliku od prve turbulentne epizode domaćeg tržišta kapitala, recentna globalna recesija uzrokovana krizom bankarskog sektora razvijenih zemalja prelila se na financijska tržišta širom svijeta pa tako i na hrvatsko tržište kapitala.

\subsection{Asimetrične korelacije na europskom tržištu kapitala}

U ovome odlomku računaju se korelacije mjesečnih nominalnih prinosa između odabranih europskih zemalja za mirni, odnosno turbulentni tržišni režim. Zbog visoke razine integriranosti promatranih tržišta (slika 2.), indikator režima je procjena stanja tržišta u EU. U slučaju da je (ex-post) vjerojatnost da je tržište EU u turbulentnom režimu veće od o.5, tj. $P\left(S_{t}^{e u}=\right.$ turbulentno $\left.\mid y_{1}^{e u}, \ldots, y_{T}^{e u}\right)>0.5$, smatramo da je tržište u turbulentnom režimu. Analogno izvodimo i indikator mirnog režima.

\section{Slika 4.}

Usporedba mjesečnih prinosa CROBEX-a te agregatnog dioničkog indeksa zemalja EU tijekom mirnih (prva slika) te turbulentnih perioda (druga slika).
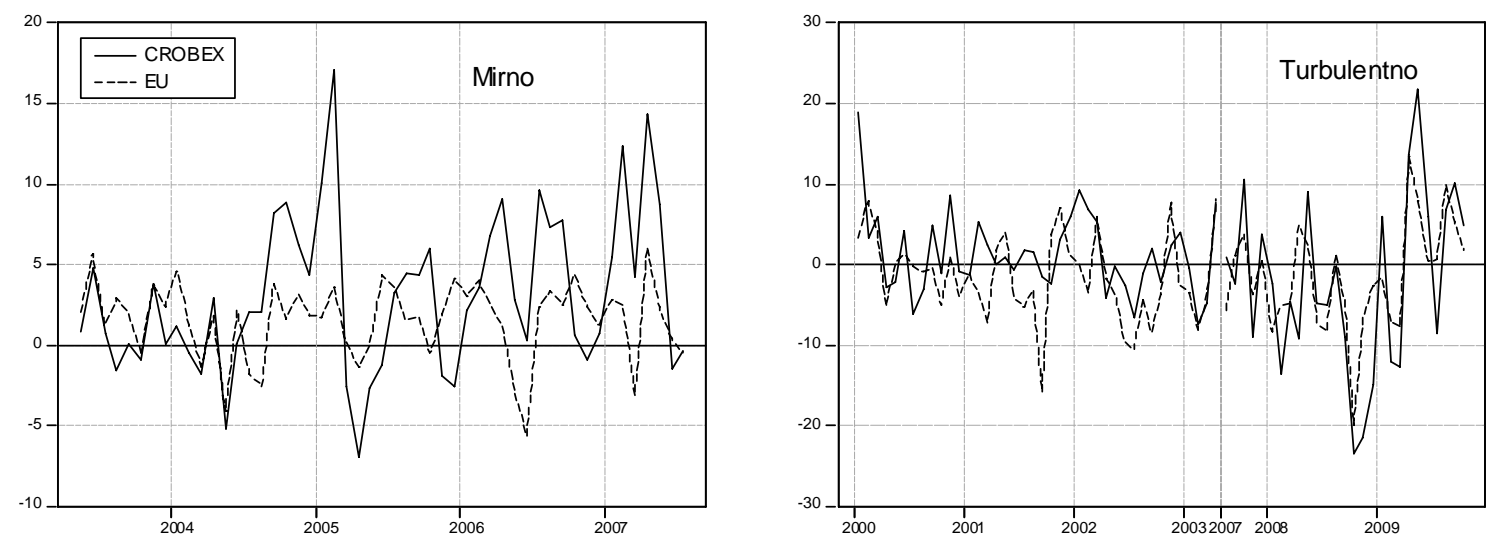

U svrhu ilustracije postojanja asimetričnosti u korelacijama, slika 4. prikazuje mjesečni prinos domaćeg dioničkog indeksa, te agregatnog indeksa EU, tijekom mirnog (prva slika) odnosno turbulentnog perioda (druga slika). Slika sugerira kako je tijekom turbulentnih razdoblja sinhroniziranost domaćeg i EU indeksa zaista značajno veća nego za mirnih perioda. Drugim riječima, fenomen asimetričnih korelacija utvrđen u slučaju razvijenih tržišta, prisutan je i u ovom slučaju.

Tablica 2 prikazuje korelacije među promatranim indeksima za dva režima, pri čemu su iznad dijagonale dane korelacije na turbulentnim tržištima, a ispod u mirnim. Za sve parove promatranih zemalja utvrđuje se postojanje asimetričnih korelacija pri čemu su korelacije između prinosa značajno više za turbulentnih razdoblja nego za mirnih. Asimetričnost među tržištima je utvrđena bez obzira da li zemlje pripadaju skupini novih ili starim zemalja Europe. U kontekstu diversifikacije međunarodnih portfelja, ovi rezultati sugeriraju kako je potencijalna korisnost diversifikacije koju strani investitori mogu ostvariti ulaganjem u tržišta nove Europe za turbulentnih razdoblja relativno ograničena. 
Tablica 2.

Asimetrične korelacije među prinosima burzi

\begin{tabular}{|l|c|c|c|c|c|c|c|c|}
\hline & Bugarska & SIE & Hrvatska & Češka & Rumunjska & Njemačka & EU \\
\hline Bugarska & I.00 & 0.55 & $0.6 \mathrm{I}$ & 0.62 & 0.58 & 0.35 & 0.42 \\
\hline SIE & 0.30 & I.00 & 0.62 & 0.89 & 0.64 & 0.76 & 0.83 \\
\hline Hrvatska & 0.04 & 0.27 & I.00 & 0.58 & 0.59 & 0.57 & 0.63 \\
\hline Češka & 0.18 & 0.86 & 0.29 & 1.00 & 0.72 & 0.71 & 0.77 \\
\hline Rumunjska & 0.18 & 0.43 & 0.34 & 0.45 & I.00 & 0.36 & 0.47 \\
\hline Njemačka & 0.05 & 0.44 & 0.28 & 0.48 & 0.15 & I.00 & 0.96 \\
\hline EU & 0.07 & 0.57 & 0.38 & 0.66 & 0.30 & 0.92 & I.00 \\
\hline
\end{tabular}

Napomena: Turbulentno (iznad dijagonale), Mirno (ispod)

\section{Asimetričnosti na hrvatskom tržištu kapitala}

U ovome odlomku se analiziraju asimetričnosti u korelacijama među prinosima odabranih dionica na hrvatskom tržištu kapitala. Pored toga, modelski se ilustriraju gubici koje investitori realiziraju pri redovitoj optimizaciji portfelja u slučaju da ignoriraju asimetričnosti na tržištu kapitala.

\section{I. Model optimizacije portfelja uz asimetrične korelacije}

Promatramo investitora koji alocira svoju imovinu kupovinom dionica $N$ različitih kompanija. Investitor u svakom trenutku može pozajmljivati sredstva kao i zaduživati se po bezrizičnoj stopi, u skladu sa svojim odnosom prema riziku. Alokacija se vrši po preporuci klasičnog Mean Variance modela čim potrebni inputi, procjene očekivanja i volatilnosti pojedinih dionica te korelacije među njima, postanu dostupni. Pretpostavimo sada da je investitor svjestan postojanja dva režima na tržištu i posljedično on uzima u obzir činjenicu da se parametri za model razlikuju među režimima. Iz tog razloga, prije optimizacije portfelja potrebno je imati informaciju o režimu u kojemu se tržište trenutno nalazi te shodno tomu i odabrati portfelj koji se drži u narednom razdoblju, mirnodopski ili onaj turbulentni. Formalizirajmo navedeno.

Optimizacija portfelja temelji se na Markov Regime Switching modelu pri čemu agregatni tržišni indeks u svakom periodu pripada jednoj od dvije različite normalne distribucije, već u ovisnosti u kojemu se režimu tržište nalazi:

$$
m_{t}^{e} \mid\left(S_{t}=i\right): N\left(\mu_{i}, \sigma_{i}^{2}\right) \text {, za } i=1,2, t=1, \ldots, T
$$

ili ekvivalentno u regresijskom obliku:

$$
m_{t}^{e}= \begin{cases}\mu_{1}+\sigma_{1} \varepsilon_{t} & \text { ako } S_{t}=1 \\ \mu_{2}+\sigma_{2} \varepsilon_{t} & \text { ako } S_{t}=2,\end{cases}
$$

gdje je $m_{t}^{e}=m_{t}-r f_{t}$ razlika prinosa tržišta i bezrizične stope, tržište $S_{t}$ može biti u jednom od stanja I ili 2, $\varepsilon_{t}$ je standardni bijeli šum te $\mu_{i}$ i $\sigma_{i}$ parametri očekivanja i standardnih devijacija po režimima 
koji se procjenjuju.

Kao i u Markose and Yang (20o8), za svaku dionicu $(i=1,2, \ldots, N)$ definiramo vezu između njenih prinosa $r_{i t}^{e}=r_{i t}-r f_{t}$ i prinosa na tržišni indeks preko CAPM regresija:

$$
r_{i t}^{e}=\alpha_{i}+\beta_{i} m_{t}^{e}+\varepsilon_{i t}, \mathrm{zat}=1, \ldots, T
$$

pri čemu su i pojedine dionice sada posredno osjetljive na promjenu režima putem veze s tržišnim indeksom. Očekivani prinos na svaku dionicu je sada:

$$
E\left(r_{i t}^{e}\right)=\alpha_{i}+\beta_{i} E\left(m_{t}^{e}\right)
$$

i varijance su dane preko:

$$
\sigma_{i}^{2}=\beta_{i}^{2} \sigma_{m}^{2}+\tilde{\sigma}_{i}^{2}
$$

gdje je $\sigma_{m}^{2}$ sistematski rizik i $\tilde{\sigma}_{i}^{2}$ idiosinkratski rizik, specifičan dionici $i$.

Naš investitor optimizira portfelj svaki mjesec koristeći Markowitzevu MV proceduru i stoga treba opskrbiti program s očekivanjima, varijancama i korelacijama među prinosima. No, ovi momenti sada ovise o režimu tržišta preko (7) i (8) i u slučaju da su parametri dviju distribucija međusobno signifikantno različiti, ignoriranjem postojanja režima investitor bira neoptimalne portfelje.

Varijabla stanja $S_{t}$ se ne opaža u stvarnom svijetu i stoga nije moguće egzaktno odrediti da li je tržište u mirnom ili turbulentnom režimu, no uz pretpostavku zakona po kojemu se tržište giba u vremenu, moguće je odrediti vjerojatnost da je tržište u trenutku $t$ u svakom od stanja. Nadalje, moguće je i procijeniti vjerojatnosti ostanka tržišta u svakom od stanja kao i vjerojatnosti prelaska u drugo stanja. Drugim riječima uz pretpostavku zakona gibanja procesa stanja tržišta $S_{t}$, ovdje pretpostavimo da je to Markovljev proces, moguće je procijeniti matricu prijelaza za dani proces. U konačnici ovo omogućava procjenu uvjetnih momenata u trenutku $t+1$ (uvjetovanih trenutnim režimom tržišta) pomoću kojih se konstruiraju inputi za optimizacijski algoritam za svaki režim.

Očekivani povrati tržišnog indeksa u $t+1$ uvjetovani trenutnim režimom tržišta (tj. uz dano $S_{t}=1 \mathrm{i}$ $\left.S_{t}=2\right)$ :

$$
\begin{aligned}
& e_{1}^{m}=E\left(m_{t+1}^{e} \mid S_{t}=1\right)=P\left(S_{t+1}=1 \mid S_{t}=1\right) \mu_{1}+P\left(S_{t+1}=2 \mid S_{t}=1\right) \mu_{2} \\
& e_{2}^{m}=E\left(m_{t+1}^{e} \mid S_{t}=2\right)=P\left(S_{t+1}=1 \mid S_{t}=2\right) \mu_{1}+P\left(S_{t+1}=2 \mid S_{t}=2\right) \mu_{2},
\end{aligned}
$$

i uvjetne varijance kao:

$$
\begin{aligned}
& \Sigma_{1}^{m}=\operatorname{Var}\left(m_{t+1}^{e} \mid S_{t}=1\right)=P\left(S_{t+1}=1 \mid S_{t}=1\right) \sigma_{1}^{2}+P\left(S_{t+1}=2 \mid S_{t}=1\right) \sigma_{2}^{2} \\
& +P\left(S_{t+1}=1 \mid S_{t}=1\right)\left(1-P\left(S_{t+1}=1 \mid S_{t}=1\right)\right)\left(\mu_{1}-\mu_{2}\right)^{2}
\end{aligned}
$$




$$
\begin{aligned}
& \sum_{2}^{m}=\operatorname{Var}\left(m_{t+1}^{e} \mid S_{t}=2\right)=P\left(S_{t+1}=1 \mid S_{t}=2\right) \sigma_{1}^{2}+P\left(S_{t+1}=2 \mid S_{t}=2\right) \sigma_{2}^{2} \\
& +P\left(S_{t+1}=2 \mid S_{t}=2\right)\left(1-P\left(S_{t+1}=2 \mid S_{t}=2\right)\right)\left(\mu_{1}-\mu_{2}\right)^{2}
\end{aligned}
$$

Za pojedinu dionicu momente procjenjujemo na sljedeći način. Najprije za svaku dionicu iz (7) slijedi:

$$
E\left(r_{i t}^{e} \mid S_{t}=j\right)=\alpha_{i}+\beta_{i} E\left(m_{t}^{e} \mid S_{t}=j\right), \text { za } j=1,2 \text {. }
$$

Grupirajmo parametre svih dionica u vektore $\alpha=\left(\alpha_{1}, \ldots, \alpha_{N}\right)^{\tau}$ i $\beta=\left(\beta_{1}, \ldots, \beta_{N}\right)^{\tau}$ i konstruirajmo vektor očekivanja:

$$
R_{j}=\left[\begin{array}{c}
E\left(r_{1 t}^{e} \mid S_{t}=j\right) \\
\vdots \\
E\left(r_{N t}^{e} \mid S_{t}=j\right)
\end{array}\right]=\alpha+\beta\left[\begin{array}{c}
E\left(m_{t}^{e} \mid S_{t}=j\right) \\
\vdots \\
E\left(m_{t}^{e} \mid S_{t}=j\right)
\end{array}\right], \mathrm{za} j=1,2
$$

Uvjetna očekivanja (ovisna o režimu u $t$ ) za period $t+1$ su tada dana s:

$$
\begin{aligned}
& e_{1}=P\left(S_{t+1}=1 \mid S_{t}=1\right) R_{1}+P\left(S_{t+1}=2 \mid S_{t}=1\right) R_{2} \\
& e_{2}=P\left(S_{t+1}=1 \mid S_{t}=2\right) R_{1}+P\left(S_{t+1}=2 \mid S_{t}=2\right) R_{2}
\end{aligned}
$$

i kovarijacijske matrice za svaki režim su sada:

$$
\Omega_{j}=\beta \beta^{\tau} \sigma_{j}^{2}+V^{2}, \mathrm{zaj}=1,2,
$$

gdje je $V=\left(\tilde{\sigma}_{1}, \ldots, \tilde{\sigma}_{N}\right)$. Konačno, uvjetne kovarijacijske matrice za period $t+1$ su:

$$
\begin{aligned}
& \Sigma_{1}=P\left(S_{t+1}=1 \mid S_{t}=1\right) \Omega_{1}+P\left(S_{t+1}=2 \mid S_{t}=1\right) \Omega_{2} \\
& \quad+P\left(S_{t+1}=1 \mid S_{t}=1\right)\left(1-P\left(S_{t+1}=1 \mid S_{t}=1\right)\right)\left(R_{1}-R_{2}\right)^{2} \\
& \Sigma_{2}=P\left(S_{t+1}=1 \mid S_{t}=2\right) \Omega_{1}+P\left(S_{t+1}=2 \mid S_{t}=2\right) \Omega_{2} \\
& \quad+P\left(S_{t+1}=2 \mid S_{t}=2\right)\left(1-P\left(S_{t+1}=2 \mid S_{t}=2\right)\right)\left(R_{1}-R_{2}\right)^{2}
\end{aligned}
$$

Koristeći se izvedenim izrazima za uvjetna očekivanja i kovarijacijske matrice investitor pri optimizaciji portfelja bira pogodne statistike, u ovisnosti o trenutnom stanju tržišta.

\subsection{Rezultati}

Predstavljeni se model sada testira na primjeru optimizacije portfelja tri dionice iz sastava indeksa Zagrebačke burze - PBZ d.d. (PBZ-R-A), Dalekovod (DLKV-R-A) i Atlantska plovidba (ATPL-R-A) pri čemu se zanemaruju transakcijski troškovi reoptimizacije portfelja. Korištenje svega tri dionice, kao i ignoriranje troškova, omogućava pregledniju prezentaciju dobivenih rezultata, dok, s druge strane, navedena ograničenja još uvijek omogućavaju ilustraciju dobrih svojstava modela temeljenog na 
asimetričnim korelacijama. Predstavljeni model stoga nema nužno ambiciju ostvarivanja natprosječnih profita pri njegovoj eventualnoj primjeni u redovitoj optimizaciji portfelja, već dobiveni rezultati u prvom redu ukazuju na trošak ignoriranja postojanja režima na tržištima kapitala, neovisno o strategiji investiranja.

Pri odabiru dionica vodilo se računa o dva osnovna kriterija. Najprije, u svrhu diversifikacije eventualnih sektorskih rizika, analiziraju se relevantne kompanije iz različitih grana hrvatskog gospodarstva. Pored toga, za provedenu je analizu bitno da su cijene odabranih dionica dostupne za relativno dug vremenski period. Analiza je provedena na mjesečnim podacima Zagrebačke burze na periodu od ožujka 20oı. godine do ožujka 2oı. godine.

Trezorski zapisi Ministarstva financija s dospijećem od jedne godine korišteni su kao bezrizična stopa u modelu ${ }^{6}$.

\subsection{Režimi na hrvatskom tržištu kapitala i asimetrične korelacije}

Model pretpostavlja da su prinosi na agregatni indeks tržišta generirani jednom od dvije distribucije, već u ovisnosti o trenutnom stanju/režimu tržišta. Tablica 3. prikazuje osnovne karakteristike prinosa na indeks tržišta za dva režima procijenjena Markov Switching modelom.

\section{Tablica 3.}

Parametri RS modela s dva režima

\begin{tabular}{|l|c|c|c|c|c|c|}
\hline & \multicolumn{3}{|c|}{ Mirno (režim I) } & \multicolumn{3}{c|}{ Turbulentno (režim II) } \\
\hline & $\mu_{1}$ & $\sigma_{1}$ & $P$ & $\mu_{2}$ & $\sigma_{2}$ & $Q$ \\
\hline Procjena & $\mathrm{I} .75$ & $4.8 \mathrm{I}$ & 0.99 & -4.06 & I0.93 & 0.94 \\
\hline Std. greška & 0.52 & 0.20 & 0.12 & 2.10 & I.IO & 0.30 \\
\hline
\end{tabular}

Mirni je režim karakteriziran pozitivnim mjesečnim prinosima od I.75\% i standardnim odstupanjem od $4.8 \mathrm{I} \%$ dok su za turbulentnog režima očekivani prinosi negativni i iznose $-4.06 \% \mathrm{uz}$ visoku mjesečnu volatilnost od I0.93\%. Posredno, putem CAPM relacija, očekivani prinosi i standardne devijacije pojedinih dionica kao i kovarijacijska/korelacijska matrica prinosa također ovise o trenutnom režimu. Tablica 4. uspoređuje korelacije među prinosima dobivene na temelju korištenog modela za mirni, odnosno turbulentni režim tržišta kapitala.

\section{Tablica 4.}

Asimetrične korelacije

\begin{tabular}{|l|c|c|c|}
\hline & PBZ & DLKV & ATPL \\
\hline PBZ & I & 0.69 & 0.55 \\
\hline DLKV & 0.30 & I & 0.53 \\
\hline ATPL & O.20 & 0.I8 & I \\
\hline
\end{tabular}

Napomena: Turbulentno (iznad); mirno (ispod).

${ }^{6} \mathrm{U}$ analizi se ne koristi tromjesečni zapis iz razloga što ta serija, za razliku od jednogodišnjih zapisa, ima velik broj nedostajućih vrijednosti na mjesečnoj razini u 2008. i 2009. godini. 
Za sve parove odabranih dionica nalazimo značajne razlike u korelacijama za identificirane režime. Za turbulentnih režima su tako veze među prinosima mjerene korelacijom redovito preko dva puta jače u odnosu na mirni režim tržišta. Imajući na umu činjenicu da korelacije među prinosima, zajedno s očekivanjima i varijancama pojedinih dionica čine osnovni input pri optimizaciji portfelja, za očekivati je da standardni modeli optimizacije koji ne uzimaju u obzir ove razlike često daju razočaravajuće rezultate u primjeni. Kako bismo dobili bolji uvid u dinamiku korelacije među dionicama kroz vrijeme, na slici 5. su prikazane vremenski ovisne korelacije za par dionica PBZ i Dalekovod. Slika ilustrira jačanje korelacija među prinosima za turbulentnih vremena. Pored toga, iako model ocjenjuje da tržište nije u turbulentnom režimu posljednjih nekoliko mjeseci korištenog uzorka, što je praćeno naglim padom korelacije, veze među dionicama u recentnom mirnom režimu su ipak jače u odnosu na mirni režim prije krize.

\section{Slika 5.}

Korelacije između prinosa na dionice Dalekovoda i PBZ-a za dva režima

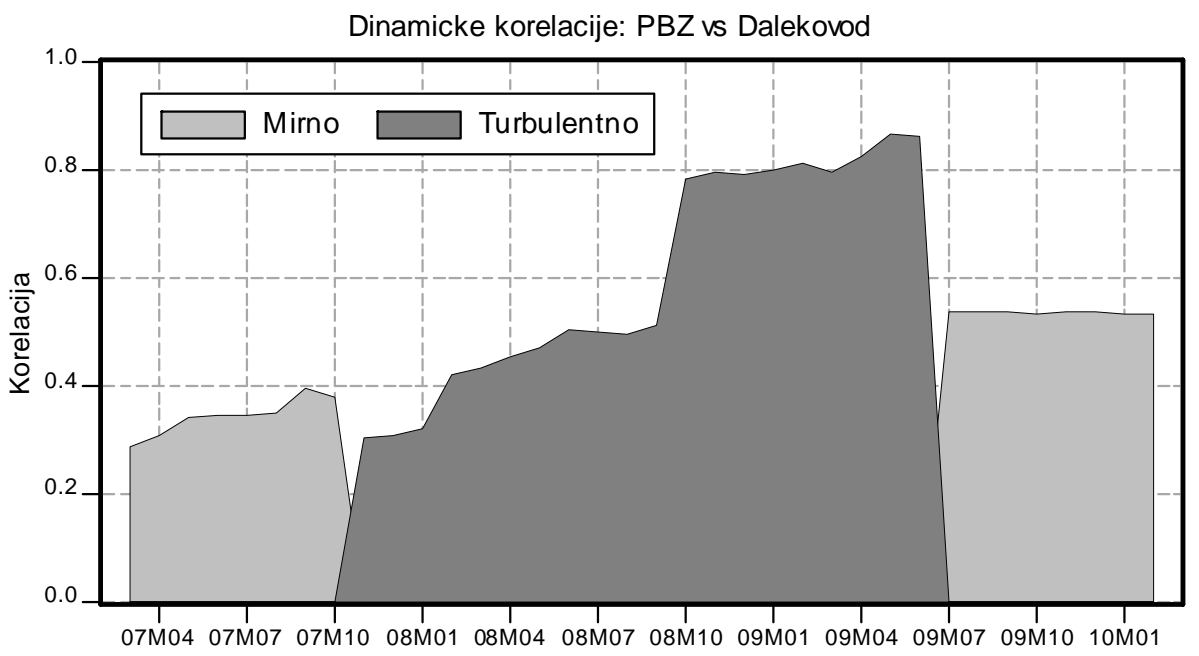

Napomena: U slučaju da je $P\left(S_{t}=i \mid y_{1}, \ldots, y_{T}\right)>0.5$ smatramo da je u trenutku $t$ tržište u režimu $i$ te se za taj vremenski trenutak prikazuje korelacija režima $i$.

Posredno su putem CAPM relacija (vidi 7) i prinosi na pojedine dionice također osjetljive na promjenu režima. Ang i Bekaert (2004) te Markose i Yang (2008) pri modeliranju asimetrične optimizacije međunarodnog portfelja, odnosno portfelja odabranih dionica Ujedinjenog Kraljevstva, pretpostavljaju da su ove relacije stabilne kroz vrijeme. No, Kunovac (2009) pokazuje kako na međunarodnom tržištu ove relacije pokazuju relativno visoku razinu nestabilnosti i uvažavanjem dinamike CAPM relacija poboljšava performanse dioničkih portfelja u out-of-sample analizi. Stoga, pored statičkih CAPM jednadžbi koje pri izračunu parametara koriste podatke čitavog uzorka računamo i pomične koeficijente koji pri izračunu koriste isključivo podatke iz posljednje četiri godine. Drugim riječima, za trenutak $t$, procjenjujemo relaciju $r_{i t}=\alpha_{t i}+\beta_{t i} m_{t}+\varepsilon_{i t}$, gdje se parametri $\alpha_{t i} \mathrm{i}$ $\beta_{t i}$ procjenjuju na periodu $t-48: t$. 
Tablica 5 .

CAPM koeficijenti

\begin{tabular}{|l|c|c|c|}
\hline & PBZ & DLKV & ATPL \\
\hline $\boldsymbol{\alpha}$ & I.22 & I.I4 & 3.2I \\
\hline Std. greška & 0.6I & 0.72 & I.50 \\
\hline $\boldsymbol{\beta}$ & I.I4 & I.2O & I.46 \\
\hline Std. greška & 0.09 & 0.IO & 0.22 \\
\hline
\end{tabular}

Tablica 5. uspoređuje procjene CAPM koeficijente za tri dionice izračunate na čitavom uzorku. Za sve promatrane dionice, procjene $\boldsymbol{\alpha}$ koeficijenata su veće od nule, iako imaju relativno veliku standardnu pogrešku. S druge strane, procjene $\boldsymbol{\beta}$ koeficijenata su veće od jedinice u svim slučajevima. To znači da su sve odabrane dionice za dobrih vremena u prosjeku rasle brže od tržišta dok su za turbulentnih vremena ostvarivale veće gubitke od tržišta.

\section{Slika 6.}

Pomični $\beta$ koeficijenti zajedno s koeficijentima izračunatim na čitavom uzorku
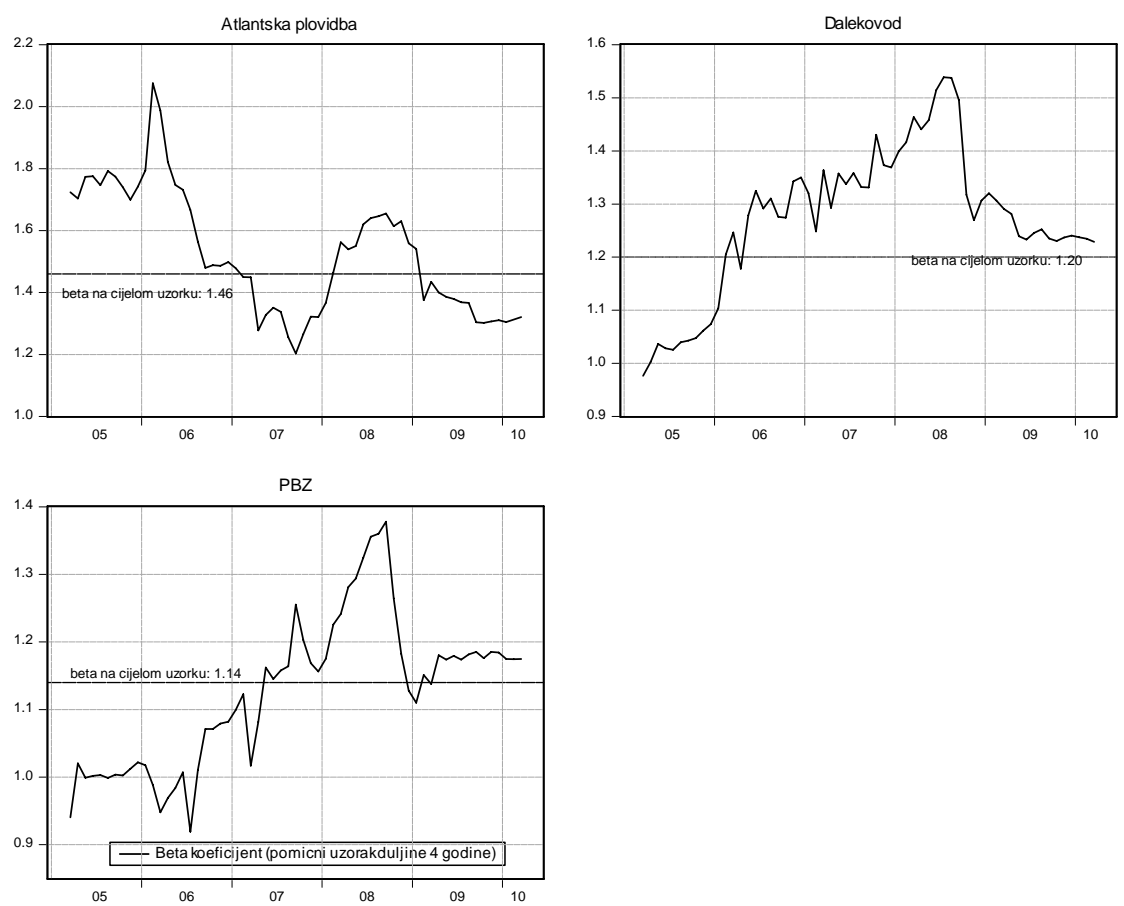

Napomena: Pomični koeficijent za trenutak $t$ procjenjuju se na podacima iz perioda $t-48: t$.

Kako bismo dobili bolji uvid u stabilnost relacija iz gornje tablice, računamo i vremenski promjenjive parametre, korištenjem uzorka duljine 48 mjeseci.

Slika 6. prikazuje pomične $\beta$ koeficijente zajedno sa statičkim. Slika sugerira da su i u slučaju hrvatske burze CAPM relacije relativno nestabilne kroz vrijeme, te statički model stoga daje tek grubu procjenu veze tržišta i pojedinih dionica. Direktna posljedica ove nestabilnosti CAPM relacija je i nestabilnost glavnih inputa modela optimizacije portfelja - očekivanih prinosa, standardnih devijacija 
te korelacija, čiji se izračun temelji na CAPM koeficijentima. Kako bismo ocijenili trošak ignoriranja ove nestabilnosti u primjeni, pored statičkog CAPM-a testirat ćemo i portfelje temeljene na dinamičkom modelu.

\subsubsection{Koliko je dobar naš Markov Switching model za CROBEX? Monte Carlo eksperiment}

Jednostavnom Monte Carlo analizom ćemo pokazati kako Markov Regime Switching model procijenjen $\mathrm{u}$ ovome radu zaista kvalitetnije opisuje empirijsku distribuciju CROBEX-a $\mathrm{u}$ od standardne normalne distribucije koja ignorira postojanje režima. U literaturi se u rijetkim slučajevima provjerava vjerodostojnost parametara procijenjenih Regime Switching metodom. Imajući na umu činjenicu da je procjena parametara ovog modela iznimno složena (Hamilton 1994.) i da ne postoji garancija da su procjene dobivene numeričkom procedurom zaista optimalne, korisno je provjeriti u kojoj su mjeri dobiveni parametri zaista u skladu s distribucijom koja se analizira, u našem slučaju s distribucijom mjesečnih prinosa na CROBEX.

\section{Slika 7.}

Empirijska gustoća prinosa na CROBEX, serije simulacija temeljene na procijenjenom Regime Switching modelu, te gustoća temeljena na normalnoj distribuciji
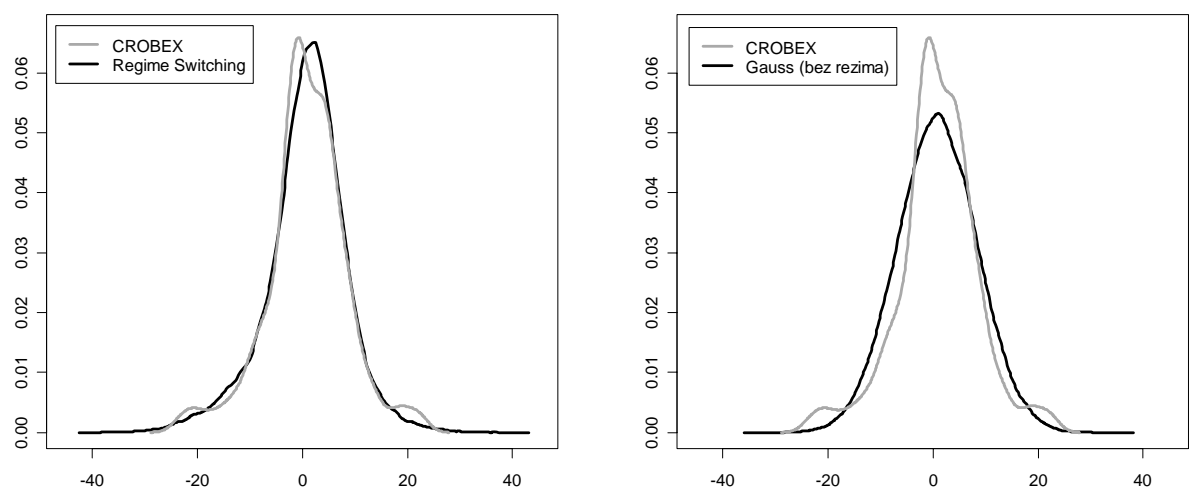

Motivirani analizom Breuning i Pagan 2004., simuliramo velik broj realizacija na temelju parametara Markov Switching modela za CROBEX (tablica 3. . $^{7}$. U prvome koraku simulira se dugačak lanac (duljine IOo ooo) s dva stanja temeljem procijenjenih vjerojatnosti tranzicije i zatim se kondicionalno o stanju simulira slučajna vrijednost iz jedne od moguće dvije normalne distribucije. Parametri dobrog MRS modela bi na ovaj način trebali proizvesti vremensku seriju čija je distribucija relativno bliska distribuciji CROBEX-a.

Slika 7. uspoređuje bliskost empirijske funkcije gustoće ${ }^{8}$ dobivene iz Markov Regime Switching modela s empirijskom gustoćom prinosa na CROBEX. U svrhu usporedbe dana je i gustoća normalne distribucije. Slika jasno ilustrira kako MRS model vjernije opisuje realizacije CROBEX-a u odnosu na

${ }^{7} \mathrm{Za}$ Monte Carlo simulacije diskretnih Markovljevih lanaca vidi Limić (2005).

${ }^{8}$ Empirijske gustoće izračunate su kernel density tehnikama (vidi Li i Racine, 2007). 
normalnu distribuciju. Iako korištenje dva režima dobro opisuje opažene prinose, model nije u stanju opisati ekstremne prinose u repovima gustoće. No, procjenom MRS modela s većim brojem režima identificira se i distribucija ovih izvanrednih pozitivnih i negativnih prinosa (Kunovac, 2009).

\subsubsection{Optimizacija portfelja}

Koristeći se MRS modelom alokacije imovine ovdje testiramo kolika je marginalna korisnost uvažavanja postojanja režima na hrvatskom tržištu kapitala. Uspoređuju se performanse standardnog Mean Variance modela koji ignorira postojanje režima s Markov Switching verzijom gdje se alokacija sredstava vrši uvažavanjem asimetričnosti veze među dionicama za različitih uvjeta na tržištu. Promatra se kumulativni prinos investicije u iznosu od jedne novčane jedinice na periodu od ožujka 2007. - ožujka 20Io. godine kako bi se modeli testirali i tijekom perioda snažnog rasta i strmog pada CROBEX-a. Pretpostavlja se da investitor može neograničeno posuđivati sredstva, kao i zaduživati se, po bezrizičnoj stopi koja je jednaka prinosu na jednogodišnje trezorske zapise Ministarstva financija. ${ }^{9}$ Dodatno, nije dozvoljen short selling dionica. Procedura se izvodi rekurzivno u sljedećem nizu koraka.

I. U trenutku $t$ procjenjuju se parametri Markov Switching modela za CROBEX,

$\boldsymbol{\theta}=\left(\mu_{1}, \mu_{2}, \sigma_{1}, \sigma_{2}, p_{11}, p_{22}\right)$, koristeći informaciju do trenutka $t$. Pored toga, korištenjem

filtriranih vjerojatnosti modela procjenjuje se trenutni režim tržišta sljedećim kriterijem: ako

$P\left(S_{t}=i \mid I_{t}\right)>0.5$ za stanje $i$, smatramo da je tržište trenutno u stanju $i$.

2. Računaju se uvjetni momenti za tržišni indeks za period $t+1$.

3. Procjenjuju se CAPM relacije između pojedinih dionica i tržišta. Pored toga, računaju se očekivani prinosi i standardne devijacije za svaku dionicu za dva režima $u t+1$. U svrhu usporedbe, pored statičkog CAPM-a računaju se dinamički parametri korištenjem uzorka $t-48$ : $t$.

4. Optimizira se portfelj tri dionice za danu razinu averzije prema riziku ${ }^{\mathrm{IO}}$ (za sve modela je averzija proizvoljno zadana i iznosi 3) i računa ostvareni prinos za dani period.

5. Dodaje se novi podatak u uzorak i ide na I (osim ako je uzorak iscrpljen).

Slika 8. uspoređuje kumulativne prinose na investiciju od jedne novčane jedinice za tri Mean Variance modela - jedan standardni koji ne uzima u obzir tržišne režime, te dva Markov Regime Switching modela.

\footnotetext{
${ }^{9}$ Uz mogućnost neograničenih bezrizičnih transakcija, racionalni će investitor držati linearnu kombinaciju rizičnog portfelja izračunatog Mean Variance algoritmom i bezrizične vrijednosnice, već u ovisnosti o razini averzije prema riziku (vidi Sharpe 1964. i Lintner 1965.).

${ }^{\text {Io } K o r i s ̌ t e n a ~ f u n k c i j a ~ k o r i s n o s t i ~ j e ~ o b l i k a ~} U=\bar{r}-\frac{1}{2} A \sigma^{2}$, pri čemu je $\bar{r}$ očekivani prinos portfelja, $\sigma^{2}$ je varijanca i $A$ mjera averzije prema riziku.
} 


\section{Slika 8.}

Akumulirani prinosi investirane jedne novčane jedinice na temelju tri modela alokacije imovine

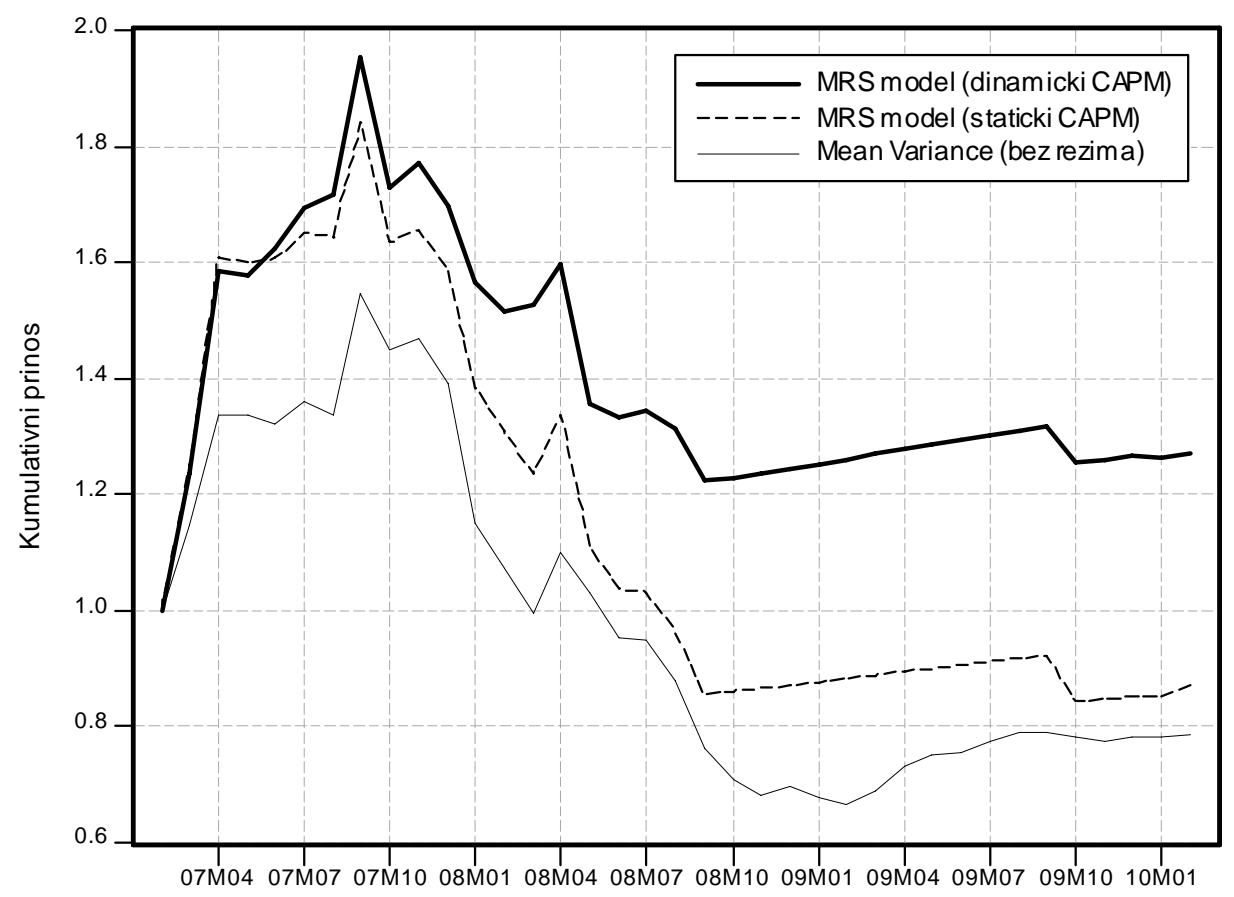

Prvi je MRS model statički i podrazumijeva stabilan odnos između pojedinih dionica i tržišnog indeksa, dok drugi, dinamički model uzima u obzir nestabilnost CAPM relacije kao što je objašnjeno ranije. Na početku promatranog razdoblja, što se vremenski podudara s razdobljem rasta tržišta, MRS portfelji temeljeni na mirnodopskim inputima perzistentno ostvaruju značajno veće prinose od standardnog MV modela. Razlog leži u agresivnijoj strategiji investiranja pri čemu se, po preporuci MRS modela, za dobrih vremena investitori često i zadužuju po bezrizičnoj stopi kako bi ta sredstva reinvestirali u rizični portfelj tri dionice. S druge strane, za turbulentnog razdoblja na domaćoj burzi tijekom nedavne financijske krize, MRS model je anticipirao nastupanje turbulentnog režima i shodno tome alocirao sredstva temeljem drugačijeg skupa parametara. Od druge polovice 2008. godine Regime Switching portfelji tako slijede krajnje konzervativnu strategiju i sva sredstva ulažu $\mathrm{u}$ bezrizičnu imovinu nakon čega rastu po stopi prinosa trezorskih zapisa. Suprotno tomu, standardni MV model je alocirao imovinu usrednjavanjem inputa iz oba režima tržišta i zbog toga je reagirao tromije od MRS modela. Posljedica takve strategije ja da je tijekom pada burze klasični MV model držao relativno velik udio rizične imovine u portfelju, u prosjeku preko 30\%, te u konačnici i ostvario puno lošije rezultate za turbulentnog razdoblja.

Dobiveni rezultati nadalje sugeriraju da je, za razliku od dosadašnje prakse u literaturi, potrebno uvažiti i nestabilnost CAPM relacije pri alokaciji portfelja korištenim modelom. Dinamički je model temeljem svježijih informacija o odnosu pojedinih prinosa s tržišnim portfeljem tako omogućio precizniju procjenu inputa za alokaciju i stoga je tijekom turbulentnog perioda bilježio znatno bolje rezultate od statičkog MRS modela. Statički MRS model za turbulentnog režima nije nadmašio klasični model bez režima. 


\section{Zaključak}

U ovome radu analizirane su razlike $u$ funkcioniranju tržišta kapitala u Hrvatskoj za mirnih vremena u odnosu na turbulentna tržišna razdoblja. Kako bi se stekao bolji uvid u narav propagacije financijskih šokova, u prvome su koraku analizirane veze domaćeg tržišta kapitala s nekoliko tržišta nove i stare Europe. Nakon toga, istražuje se i dinamika odnosa među odabranim dionicama CROBEXa. Provedena empirijska analize rezultirala je sljedećim osnovnim nalazima.

Za sva promatrana europska tržišta, uključujući hrvatsko, formalno su identificirana dva bitno različita režima korištenjem Markov Regime Switching modela. Prvi je režim karakteriziran pozitivnim prinosima uz nisku volatilnost i stoga je identificiran kao mirni režim. S druge strane, $u$ drugom, turbulentnom režimu je volatilnost prinosa značajno viša u odnosu na mirni režim i očekivani prinosi su sada redovito negativnog predznaka. Nadalje, sve izraženija vremenska sinhroniziranost tržišnih režima u promatranim zemljama sugerira povećanu razinu integracije tržišta nove i stare Europe, pri čemu Hrvatska, kao jedina ne-članica EU među promatranim tržištima, ne predstavlja iznimku u ovome kontekstu. Ovakva bliskost dinamike na tržištima kapitala Europe u prvome se redu pripisuje širim ekonomskim vezama među promatranim zemljama.

U skladu s prethodno provedenim analizama za razvijena tržišta kapitala (Ramchand i Susmel, 1997; Longin i Solnik, 200I; Ang i Chen, 2002), za sve parove ovdje promatranih zemalja provedena analiza sugerira postojanje asimetričnih korelacija među burzama na mjesečnoj razini, pri čemu su korelacije između prinosa značajno više za turbulentnih razdoblja u odnosu na mirna. Asimetričnost je utvrđena neovisno o tomu da li zemlje pripadaju skupini novih ili starih zemalja Europe. U kontekstu diversifikacije međunarodnih portfelja, dobiveni rezultati sugeriraju kako je potencijalna korisnost diversifikacije koju strani investitori mogu ostvariti ulaganjem u tržišta nove Europe za turbulentnih razdoblja relativno ograničena.

Posebna je pažnja posvećena identifikaciji režima te testiranju asimetričnosti korelacija za dionice na tržištu kapitala u Hrvatskoj. Pored toga, modelski se ilustrira gubitak koji investitori ostvaruju na tržištu u slučaju da ignoriraju postojanje režima pri redovitoj reoptimizaciji portfelja. Za sve parove odabranih dionica provedena analiza nalazi značajne razlike u korelacijama za identificirane režime. Za turbulentnih režima su tako veze među prinosima mjerene korelacijom redovito preko dva puta jače u odnosu na mirni režim tržišta. Imajući na umu činjenicu da korelacije među prinosima, zajedno s očekivanjima i varijancama pojedinih dionica čine osnovni input pri optimizaciji portfelja, za očekivati je da standardni modeli optimizacije koji ne uzimaju u obzir razlike u inputima za razne režime tržišta često daju razočaravajuće rezultate u primjeni. Kako bi se ovo provjerili za slučaj investiranja na domaćem tržištu, uspoređene su performanse standardnog Mean Variance modela koji ignorira postojanje režima s Markov Switching verzijom Mean Variance modela gdje se alokacija sredstava vrši uvažavanjem asimetričnosti veze među dionicama za različitih uvjeta na tržištu. Dobiveni rezultati provedene out-of-sample analize jasno ukazuju na važnost uvažavanja režima pri optimizaciji portfelja. Za dobrih vremena, Markov Switching portfelji temeljeni na inputima 
usklađenima s mirnim režimom ostvaruju značajno više prinose od klasičnog modela. Slično, za turbulentnih razdoblja, klasični model koji ignorira režime sporo anticipira nastanak krize i posljedično, drži u svome sastavu velik dio rizične imovine što u konačnici rezultira slabijim performansama u odnosu na Markov Switching model.

U kontekstu metodologije, ovaj rad nadograđuje postojeću literaturu s dva detalja. Korišteni model alokacije imovine pretpostavlja da se jedino agregatni indeks tržišta eksplicitno pod utjecajem režima tržišta, dok su pojedine dionice posredno pod utjecajem režima putem CAPM relacija između dionice i tržišta. No, budući da ove relacije za hrvatsko tržište kapitala nisu stabilne kroz vrijeme provjereno je da li korekcija modela za ovu nestabilnost poboljšava performanse Markov Switching modela. Pokazalo se da je model koji uvažava nestabilnost parametara omogućio precizniju procjenu inputa za alokaciju i stoga je tijekom turbulentnog perioda bilježio znatno bolje rezultate od standarnog MRS modela. Drugi tehnički detalj odnosi se na provjeru vjerodostojnosti parametara MRS modela. Jednostavnom Monte Carlo analizom pokazano je da je korištenim modelom zaista moguće vjerno replicirati distribuciju mjesečnih prinosa CROBEX-a. Za razliku od distribucija impliciranih Markov Switching modelom, standardna normalna distribucija nezadovoljavajuće aproksimira ostvarene prinose na CROBEX.

Ovaj rad utvrđuje postojanje fenomena asimetričnih korelacija na tržištima kapitala u Hrvatskoj kao i u ostalim zemljama srednje i istočne Europe te, pored toga, ukazuje na trošak ignoriranja postojanja režima pri redovitoj reoptimizaciji portfelja. Utvrđenu asimetričnost djelomično objašnjava činjenica da su kao posljedica ekonomske integriranosti zemalja Europe, promatrana tržišta često izložena istim realnim šokovima koji se u konačnici reflektiraju i na tržišta kapitala. U kojoj je mjeri izloženost zajedničkim šokovima zaista odgovorna za korelacije na međunarodnim tržištima kapitala, a koliko je tomu uzrok eventualno iracionalno oponašanje dinamike razvijenih tržišta na tržištima u razvoju ostaje zanimljivo neodgovoreno pitanje. 


\section{Literatura}

Ang, A. and Bekaert, G., 2004. "How do regimes affect asset allocation”. Financial Analysts Journal, 6o, 86-99.

Ang, A. and Chen, J., 2002. "Asymmetric correlations of equity portfolios". Journal of Financial Economics, 63 (3), 443-494.

Black, F. and Litterman, R., 1992. "Global Portfolio Optimization”. Financial Analysts Journal, 48 (5), 28-43.

Breunig, R. V. and Pagan, A. R., 2004. "Do Markov-switching models capture nonlinearities in the data?: Tests using nonparametric methods". Mathematics and Computers in Simulation, 64 (3-4), 4OI407.

Calvo, G. A. and Mendoza, E. G., 200o. "Rational contagion and the globalization of securities markets". Journal of International Economics, 5I (I), 79-II3.

Calvo, S., Reinhart, C., I996. "Capital flows to Latin America : Is there evidence of contagion effects?" Policy Research Working Paper Series, No. 1619. Washington: The World Bank.

Égert, B. and Kočenda, E., 2007. "Time-Varying Co-movements in Developed and Emerging European Stock Markets: Evidence from Intraday Data” [online]. William Davidson Institute Working Papers Series, WP86I. Available from: [http://home.cerge-ei.cz/kocenda/papers/BiARCHStock.pdf].

Forbes, K. J. and Rigobon, R., 2002. "No Contagion, Only Interdependence: Measuring Stock Market Co-movements". Journal of Finance, 57 (5), 2223-226I.

Fruk, M. and Huljak, I., 2004. “Testiranje Sharpe-Lintnerovog modela na Zagrebačkoj burzi” [online]. Financial Theory and Practice, 28 (I), 77-91.

Hamilton, J. D., I989. "New Approach to the Economic Analysis of Nonstationary Time Series and the Business Cycle". Econometrica, 57 (2), 357-384.

Hamilton, J. D., 1990. "Analysis of time series subject to changes in regime". Journal of Econometrics, 45 (I-2), 39-70.

Hamilton, J. D., 1994. Time Series Analysis. Princeton: Princeton University Press.

Jakšić, S., 2007. "Primjena Markowitzeve teorije na tržište dionica Zagrebačke burze". Zbornik Ekonomskog fakulteta u Zagrebu, 5 (I), 33I-344.

Kim, C.-J., I994. "Dynamic linear models with Markov-switching”. Journal of Econometrics, 60 (I-2), I22.

Kunovac, D., 2009. International Asset Allocation under Regime Switching, University of Essex mimeo.

Latković, M. and Boršić, D., 200o. "Rizik nelikvidnosti aktivno i pasivno upravljanih dioničkih portfelja”. Računovodstvo i financije, 46 (6), I8-22.

Latković, M., 200o. "Internacionalna diverzifikacija portfelja za hrvatsko tržište kapitala” [online]. Hrvatska gospodarska revija. Available from: [http://www.phy.hr/ laci/art/int-div.pdf].

Latković, M., 200I. "Nesinkrono trgovanje i proračun sistematskog rizika” [online]. Available from: [http://www.phy.hr/I26laci/art/beta.pdf].

Li, Q. and Racine, J. S., 2007. Nonparametric Econometrics: Theory and Practice. Princeton: Princeton University Press.

Limić, N., 2005. Monte Carlo simulacije slučajnih veličina, nizova i procesa. Zagreb: Element.

Lintner, J., 1965. "Security prices, risk and maximal gains from diversification”. Journal of Finance, 20, 587-616.

Longin, F., and Solnik, B., 20oI. "Correlation Structure of International Equity Market During Extremely Volatile Periods". Journal of Finance, 56 (2), 649-676.

Markose, S. M and Yang, J., 2008. Optimal Portfolio Selection with Dynamic Regime Switching Weights. Mimeo, University of Essex.

Markowitz, H. M., 1952. "Portfolio Selection". The Journal of Finance, 7 (I), 77-91.

Mullainathan, S., 1998. A memory based model of bounded rationality. Cambridge: MIT.

Ramchand, L. and Susmel, R., 1998. "Volatility and cross correlation across major stock markets". Journal of Empirical Finance, 5 (4), 397-416. 
Samuelson, P., 1966. "Science and Stocks”. Newsweek, September I9.

Sharpe, W. F., I964. "Capital asset prices: A theory of market equilibrium under conditions of risk". Journal of Finance, 19 (3), 425-442.

Syllignakis, M. and Kouretas, G., 2006. "Long and Short-Run Linkages in CEE Stock Markets: Implications for Portfolio Diversification and Stock Market Integration". William Davidson Institute Working Papers Series, WP832.

Syriopoulos, T., 2004. "International portfolio diversification to Central European stock markets". Applied Financial Economics, I4 (17), I253-I268. 